\title{
Relative importance of strategies for improving the sample size selection and reporting of small randomized clinical trials in anesthesiology
}

\author{
Emine Ozgur Bayman, PhD $\cdot$ Franklin Dexter, MD, PhD, FASA
}

Received: 24 January 2018/Accepted: 5 February 2018/Published online: 19 March 2018

(C) Canadian Anesthesiologists' Society 2018

In the current issue of the Journal, Chow et al. ${ }^{1}$ report the results of a survey of the quality of sample size calculations for two-arm, parallel group, superiority, randomized clinical trials (RCTs) published in six high-impact-factor anesthesiology journals. Trials reporting continuous or binary outcomes published in 2010 and 2016 were included. The authors recorded the variables used to estimate sample size and the actual outcome measures reported for treatment and control groups in the trials. Among 255 RCTs published in these journals in 2010 and 2016, the sample size calculations were not presented or were reported with insufficient data for replication in 33/ $143(23 \%)$ and 24/112 (21\%) of reports, respectively.

This finding, although disappointing, is consistent with previous research reports. ${ }^{2}$ Authors of RCTs should be expected to adhere to, and journal editors to enforce, the relevant reporting elements of the CONSORT statement. ${ }^{3}$ The necessary components for trials with binary or continuous outcomes are a) the primary outcome for which the sample size calculation was based, b) the estimated outcome for the control group, c) the clinically meaningful difference, d) the planned test, e) type I and type II error rates, and f) whether the test is one- or two-

E. O. Bayman, PhD $(\bowtie) \cdot$ F. Dexter, MD, PhD, FASA

Department of Anesthesia, University of Iowa, 200 Hawkins Drive, 6439 JCP, Iowa City, IA 52242, USA

e-mail: Emine-Bayman@UIowa.edu

E. O. Bayman, $\mathrm{PhD}$

Department of Biostatistics, University of Iowa, Iowa City, IA, USA

F. Dexter, MD, PhD, FASA

Division of Management Consulting, University of Iowa, Iowa City, IA, USA sided. For a continuous outcome, the assumed common standard deviation (SD) should be included as well.

Chow et al. also reported that the actual values for the outcomes of the control groups were within $10 \%$ of their expected values for only 26/62 (42\%) and 24/68 (35\%) of the studies performed in 2010 and 2016, respectively, although the observed and expected values for the treatment groups were similar less frequently [14/62 (23\%) and $17 / 68$ (25\%), respectively]. That there were more accurate estimates for the control groups than the treatment groups could have been expected as the controls often represent a "usual care" group, and there are generally historical data available on which to base better estimates. In contrast, the authors found that most of the RCTs expected a larger effect size than that observed. In other words, the actual observed effect sizes were usually less than what were considered clinically important differences during the sample size design.

For example, for RCTs with a binary outcome, the actual effect size was less than the expected effect size used for the sample size calculation in 16/27 (59\%) and 23/ $30(77 \%)$ of the studies in 2010 and 2016, respectively. The corresponding rates for studies with a continuous outcome were $16 / 35(46 \%)$ in 2010 and 25/38 (66\%) in 2016. These findings also match what should be expected for RCTs. At the time of the sample size calculation, researchers generally are uncertain of the expected size of the treatment effect. The expected outcome for the treatment group is estimated using the expected outcome rate in the control group and the minimum clinically meaningful difference. "Expected" in this context generally is the minimum clinically meaningful difference, not the investigators' best estimate of how effective the treatment might be. The actual effect size being less than the expected effect size parallels what occurs in most 
clinical trials - i.e., not finding a statistically significant difference for the primary outcome variable. Because the goals of clinical trials are generally improved patient outcomes, most trials fail to detect a statistically significant difference.

The principal novel finding of Chow et al.'s current study involves pooled SDs. Prior to this study, one potential critique of small RCTs in anesthesia was the nearly complete absence of using an iterative adjustment of the sample size. In part because RCTs are small, a single sample size adjustment could be performed, with blinding, once the more accurate pooled SD is known. This approach, referred to as an "internal pilot study," is generally performed with an unblinded interim analysis. ${ }^{4}$ The estimated common SD can be updated based on observations from a previously calculated subset of enrollment (e.g., half of the initial sample size). This updated SD is used to recalculate the final sample size of the trial. Most authors recommend using the "restricted design," which allows only upward adjustment of the sample size calculation. Thus, with the restricted design, if the pooled SD observed for the internal pilot data is smaller than the original estimate of the $\mathrm{SD}$, the original sample size is used. ${ }^{5}$ Conversely, if the pooled SD observed for the internal pilot data is greater than the original estimate of the SD, the target sample size would be greater than the original sample size. There are also "unrestricted designs," which allow mathematically for both upward and downward adjustments. ${ }^{6}$ Friede and Keiser's review article is recommended for readers interested in learning more about internal pilot studies. ${ }^{4}$ Regardless of which method is used, the price of using internal pilot studies is the need for a slightly greater total sample size to maintain the prespecified type I error rate. Planned use of an internal pilot study should be indicated at the time of registering the RCT with ClinicalTrials.gov.

Observational studies generally precede randomized trials. If, at the design stage of the RCT, an investigator perceives that the minimum clinically important difference is unknown, it is recommended that historical data from electronic medical records be used or an observational study be performed prior to the RCT to make this determination. Usually, however, neither is necessary because it is the SD that is unknown, not the difference to be detected.

Another important finding from the Chow et al. study ${ }^{1}$ is that, for continuous primary outcome variables, 12/21 (57\%) of the RCTs in 2010 and 11/21 (52\%) of the RCTs in 2016 reported an actual SD that was less than the expected SD. The implication is that the estimates of variability are not consistent underestimates of actual variability. The assumption that data are more variable results in a larger sample size to be estimated, suggesting that the addition of internal pilots to small RCTs in anesthesiology would generally not be fruitful. Thus, the absence of the routine use of internal pilot studies (i.e., single adjustments to the sample size) does not indicate a particular weakness of our specialty's clinical trials.

In conclusion, we applaud Chow et al. for the hard work of determining the estimated and actual effect sizes and SDs in several large anesthesia journals. One implication of their results is the obvious need for every component of the sample size calculation to be reported in publications so that calculations can be replicated. We encourage investigators and editors to follow the recommended CONSORT checklist. A clear and accurate statement of the minimum clinically meaningful difference in both binary and continuous outcomes is frequently absent from the published reports of anesthesiology trials. Recognizing and addressing this absence presents an important opportunity to improve both the design and reporting of perioperative research.

\section{Importance relative des stratégies pour l'amélioration du choix de la taille de l'échantillon et du compte rendu de petits essais cliniques randomisés en anesthésiologie}

Dans ce numéro du Journal, Chow et coll. ${ }^{1}$ rapportent les résultats d'une enquête sur la qualité des calculs de la taille de l'échantillon pour des études cliniques randomisées (ECR) de supériorité, à deux groupes et groupes parallèles, publiées dans 6 journaux d'anesthésiologie à facteur d'impact élevé. Des études décrivant des résultats soit continus, soit binaires publiés en 2010 et 2016 ont été inclus. Les auteurs ont consigné les variables utilisées pour estimer la taille des échantillons et les véritables mesures des résultats rapportées pour les groupes de traitement et les groupes témoins de ces études. Parmi les 255 études cliniques randomisés dans ces journaux en 2010 et 2016, les calculs de la taille des échantillons n'ont pas été présentés, ou l'ont été avec des données insuffisantes pour permettre de les répliquer, dans respectivement $23 \%$ (33/ $143)$ et $21 \%(24 / 112)$ des articles.

Cette constatation, quoique décevante, est concordante avec les comptes rendus des études déjà publiées. ${ }^{2}$ On devrait pouvoir s'attendre à ce que les auteurs d'ECR adoptent (et que les rédacteurs des journaux exigent) les 
éléments pertinents de publication figurant dans la déclaration CONSORT. ${ }^{3}$ Les éléments nécessaires pour les essais publiant des résultats continus ou binaires sont a) le critère d'évaluation principal pour lequel le calcul de la taille de l'échantillon a été établi, b) le résultat estimé pour le groupe témoin, c) la différence cliniquement significative, d) le test prévu, e) les taux d'erreur de type I et de type II et f) si le test est uni ou bilatéral. Pour un résultat de type continu, l'écart-type (ET) supposé devrait être également inclus.

Chow et coll. ont aussi indiqué que les valeurs réelles des résultats des groupes témoins se situaient dans une limite de $10 \%$ des valeurs attendues pour seulement $42 \%$ $(26 / 62)$ et $35 \%(24 / 68)$ des études réalisées respectivement en 2010 et 2016, alors que les valeurs observées et attendues pour les groupes de traitement étaient moins souvent similaires (respectivement, $23 \%$ [14/62] et $25 \%$ [17/68]). Que des estimations plus précises pour les groupes témoins que pour les groupes de traitement aurait été normal dans la mesure où les groupes témoins représentent souvent des groupes de «traitements usuels » et on dispose habituellement de données historiques sur lesquelles appuyer de meilleures estimations. En revanche, les auteurs ont constaté que la majorité des ECR prévoyaient une ampleur de l'effet supérieure à ce qui a été observé. En d'autres termes, la véritable ampleur observée des effets a été habituellement inférieure à celle qui était jugée une différence cliniquement importante au cours de la conception de la taille des échantillons.

Par exemple, dans le cas des essais randomisés à résultats binaires, l'ampleur de l'effet véritable était inférieure à celle utilisée pour le calcul de la taille de l'échantillon dans $59 \%(16 / 27)$ et $77 \%$ (23/30) études en, respectivement, 2010 et 2016. Les pourcentages correspondants pour les études portant sur des résultats continus étaient $46 \%(16 / 35)$ en 2010 et $66 \%(25 / 38)$ en 2016. Ces constatations correspondent également à ce qu'on devrait attendre pour des ECR. Au moment du calcul de la taille de l'échantillon, les chercheurs sont habituellement incertains quant à l'ampleur attendue de l'effet thérapeutique. Le résultat attendu dans le groupe de traitement est estimé à partir du taux de résultats attendus dans le groupe témoin et d'une différence cliniquement significative minimum. Dans ce contexte, «Attendu» représente habituellement la différence cliniquement significative minimum et non la meilleure estimation des investigateurs sur l'efficacité potentielle du traitement. L'ampleur véritable de l'effet, inférieure à l'ampleur attendue, reflète ce qui survient dans la majorité des études cliniques - c'est-à-dire, ne pas trouver de différence statistiquement significative pour la variable du critère d'évaluation principal. Dans la mesure où les objectifs des études cliniques sont habituellement une amélioration des résultats pour les patients, la majorité d'entre elles ne parviennent pas à détecter une différence statistiquement significative.

La principale constatation novatrice de l'étude de Chow et coll. implique les ET regroupés. Avant cette étude, une critique potentielle des petits ECR en anesthésie était la quasi totale absence d'utilisation d'un ajustement répété de la taille de l'échantillon. En partie du fait de la petite taille des ECR, un unique ajustement de la taille de l'échantillon pourrait être fait, avec insu, après qu'un ET regroupé plus précis soit connu. Cette approche, habituellement appelée « étude pilote interne », est généralement réalisée sur une analyse intérimaire non soumise à l'insu. ${ }^{4}$ L'ET courant estimé peut être actualisé à partir d'observations provenant d'un sous-groupe de recrutements calculés antérieurement (par exemple la moitié de la taille de l'échantillon initial). Cet ET actualisé sert à recalculer la taille de l'échantillon définitif de l'étude. La plupart des auteurs recommandent d'utiliser un «devis restreint» qui ne permet qu'un ajustement dans le sens d'une augmentation de la taille de l'échantillon. Ainsi, avec le devis restreint, la taille de l'échantillon d'origine est utilisée si l'ET regroupé observé pour les données du pilote interne est inférieur à l'estimation initiale de l'ET. $^{5}$ Au contraire, si l'ET regroupé observé pour les données du pilote interne est supérieur à l'estimation initiale de l'ET, la taille de l'échantillon cible devrait être plus grande que celle de l'échantillon d'origine. Il existe aussi des «devis non restreints » qui permettent de faire des ajustements mathématiques vers le haut et vers le bas. ${ }^{6}$ La lecture de l'article de synthèse de Frit et Keiser est recommandée pour les lecteurs souhaitant en savoir plus sur les études des pilotes internes. ${ }^{4}$ Quelle que soit la méthode utilisée, le prix à payer pour l'utilisation d'études d'un pilote interne est le besoin d'un échantillon total légèrement plus grand pour maintenir le taux d'erreur préspécifié de type I. L'utilisation anticipée d'une étude de pilote interne doit être indiquée au moment de l'enregistrement de l'ECR sur ClinicalTrials.gov.

Des études observationnelles précèdent habituellement les essais randomisés. $\mathrm{Si}$, au stade de la conception de l'ECR, un investigateur perçoit que la différence minimum cliniquement importante est inconnue, on recommande d'utiliser les données historiques provenant de dossiers médicaux électroniques ou de réaliser une étude observationnelle avant l'ECR pour obtenir cette information. Néanmoins, cela n'est habituellement pas nécessaire parce que c'est l'ET qui est inconnu et non la différence à détecter.

Une autre constatation importante de l'étude de Chow et coll. ${ }^{1}$ est que, pour des variables de critères d'évaluation principaux continus, $57 \%(12 / 21)$ des ECR de 2010 et 
$52 \%(11 / 21)$ des ECR de 2016 ont indiqué un ET réel inférieur à l'ET attendu. Cela implique que les estimations de variabilité ne sont pas des sous-estimations constantes de la véritable variabilité. L'hypothèse selon laquelle les données sont plus variables entraîne la nécessité d'estimer un plus grand échantillon, ce qui laisse penser que l'ajout de pilotes internes à des petits ECR en anesthésiologie s'avérerait habituellement sans intérêt. Ainsi, l'absence d'utilisation habituelle d'études pilotes internes (c'est-à-dire, ajustements uniques de la taille de l'échantillon) n'indique pas une faiblesse particulière des études cliniques dans notre spécialité.

En conclusion, nous félicitons Chow et coll. pour leur difficile travail de détermination de l'ampleur de l'effet réel et estimé et des ET dans plusieurs grands journaux d'anesthésie. Une implication de leurs résultats est le besoin évident de décrire chaque élément du calcul de taille des échantillons dans les articles publiés pour permettre de les répliquer. Nous encourageons les investigateurs et rédacteurs à suivre la liste de contrôle recommandée de CONSORT. Un énoncé limpide et précis de la différence cliniquement significative minimum concernant les résultats binaires et les résultats continus est souvent absent des comptes rendus publiés des études d'anesthésiologie. Reconnaître et répondre à cette absence constitue une importante occasion d'améliorer à la fois la conception et la description de la recherche périopératoire.

Conflicts of interest None declared.

Editorial responsibility This submission was handled by Dr. Gregory L. Bryson, Deputy Editor-in-Chief, Canadian Journal of Anesthesia.
Funding This research did not receive any specific grant from funding agencies in the public, commercial, or not-for-profit sectors.

Conflits d'intérêts Aucun déclaré.

Responsabilité éditoriale Cet article a été traité par le $\mathrm{D}^{\mathrm{r}}$ Gregory L. Bryson, Rédacteur en chef adjoint, Journal canadien d'anesthésie.

Financement Cette recherche n'a reçu aucune subvention particulière des agences de financement des secteurs publics, commerciaux ou à but non lucratif.

\section{References}

1. Chow JT, Turkstra TP, Yim E, Jones PM. Sample size calculations for randomized clinical trials published in anesthesiology journals: a comparison of 2010 versus 2016. Can J Anesth 2018; 65. DOI: https://doi.org/10.1007/s12630-018-1109-z.

2. Dexter F, Shafer SL. Narrative review of statistical reporting checklists, mandatory statistical editing, and rectifying common problems in the reporting of scientific articles. Anesth Analg 2017; 124: 943-7.

3. Schulz KF, Altman DG, Moher D; CONSORT Group. CONSORT. statement: updated guidelines for reporting parallel group randomised trials. BMJ 2010; 2010(340): c332.

4. Friede T, Kieser M. Sample size recalculation in internal pilot study designs: a review. Biom J 2006; 48: 537-55.

5. Wittes $J$, Brittain E. The role of internal pilot studies in increasing the efficiency of clinical trials. Stat Med 1990; 9: 65-71; discussion 71-2.

6. Birkett MA, Day SJ. Internal pilot studies for estimating sample size. Stat Med 1994; 13: 2455-63. 